\title{
JAUNIMO MOKYKLŲ MOKSLEIVIŲ FIZINIO AKTYVUMO SĄSAJOS SU MOKYMOSI MOTYVACIJA, SAVIGARBA IR SOCIALINE INTEGRACIJA
}

\author{
Edita Vainiené $\dot{1}^{1}$ Kęstutis Kardelis ${ }^{2}$ \\ Kauno P. Eimučio jaunimo mokykla ${ }^{1}$, Lietuvos kūno kultūros akademija², Kaunas, Lietuva
}

\begin{abstract}
Edita Vainienė. Sporto psichologijos magistrè. Psichologinės-socialinės diagnostikos laboratorijos vedèja. Lietuvos kūno kultūros akademijos Socialinių kūno kultūros ir sporto problemų tyrimų laboratorijos jaunesnioji mokslo darbuotoja. Mokslinių tyrimų kryptys: psichosocialinė sveikata; mokymosi motyvacija; fizinis aktyvumas.
\end{abstract}

\begin{abstract}
SANTRAUKA
Jaunimo mokyklu mokytojai kasdieniame darbe susiduria su paaugliais, kurie čia patenka dèl j̇vairiu priežasčiu: nepakankamos tèvu priežiūros, sunkios šeimu socialinès-ekonominès padèties, pakitusio savęs vertinimo, sumažejusiu siekiu ir nesèkmiu mokymosi procese, per didelio nerimo, savarankiškumo siekimo, polinkio í praktinę bei sportinę veikla, intelekto sandaros, emociju ir elgesio sutrikimu. Todèl šiu mokyklu mokytojams neretai kyla sunkumu norint paskatinti mokiniu mokymosi motyvacija, kuri, be sqsaju su psichosocialiniais sveikatos rodikliais (savigarba, socialine integracija), nustatytais kitu tyrejju darbuose, gali büti susijusi ir su fiziniu aktyvumu. Pastaroji veikla, mūsu nuomone, galètu būti vienu iš veiksniu, galinčiu daryti teigiama ìtaka mokiniu požiūriui i mokykla.
\end{abstract}

Išsakyti teiginiai skatino tyrima, kurio tikslas — atskleisti jaunimo mokyklu moksleiviu fizinio aktyvumo, mokymosi motyvacijos ir psichosocialines sveikatos sqsajas. Jo metu taikyti šie mokymosi motyvacijos nustatymo metodai: anketinè apklausa raštu (Zambacevičiené, Janulytè, 1998) ir interviu (Pileckaitè-Markoviené, 2001). Vertinant moksleiviu socialinę integracija / izoliacija taikytas A. Eder (1989) klausimynas, kuriame pateikti klausimai ir apie ju fizini aktyvumq. Moksleiviu savigarba tirta pagal C. Curie (1987) pasiūlyta metodika.

Tiriamaja imtị sudare 15-17 metu moksleiviai (97 vaikinai ir 26 merginos) iš visu Kauno miesto jaunimo mokyklu $(n=123)$.

Gauti rezultatai parode, kad jaunimo mokyklos moksleivius mokytis motyvuoja tokios mokymosi paskatos kaip noras tęsti mokslus, pareigos jausmas, pastangos išvengti draugu kritikos ir noras užangus mokèti gerai dirbti.

Nustatytas psichosocialinès sveikatos rodikliu (socialinès integracijos ir savigarbos) tarpusavio ryšys, t. y. aukštos socialinès integracijos moksleiviai buvo ir aukštos savigarbos. Lyties skirtumu tiriant vaikinu ir merginu socialine integracija ir savigarba tyrimas neatskleide, o mokymosi motyvacijos bei pasiekimu rodmenys merginu yra aukštesni nei vaikinu.

Fizinio aktyvumo grupèse nustatyta, kad vaikinai yra fiziškai aktyvesni nei merginos. Tyrimo rezultatai parodè, kad fiziškai aktyvesni moksleiviai yra aukštesnès savigarbos, jie geriau integruoti ir socialiai.

Lyginamoji moksleiviu mokymosi motyvacijos, psichosocialinès sveikatos rodikliu ir fizinio aktyvumo analize atskleide ju tarpusavio ryšius: aukštesnès savigarbos buvo fiziškai aktyvesni ir geriau socialiai integruoti moksleiviai. Aukštesni savigarbos rodikliai tu moksleiviu, kuriuos skatina mokytis tokios paskatos kaip noras sužinoti ka nors naujo, užaugus mokèti gerai dirbti ir tinkamai bendrauti su tèvais, mokytojais, draugais.

Raktažodžiai: fizinis aktyvumas, mokymosi motyvacija, psichosocialinès sveikatos rodikliai.

\section{IVADAS}

$\mathrm{V}$ isais amžiaus tarpsniais, kada kalbama apie moksleivių sveikatą, pabrěžiamas aktyvios fizinès veiklos trūkumas. Nors vaikai ir paaugliai yra aktyvesni nei dauguma suaugusiujų, tačiau technikos amžius, jo pažanga, socialinė aplinka lemia mokiniu fizini aktyvumą ir nebūtinai teigiamą. Vis labiau skatinamas geras kompiuterinis raštingumas, užsienio kalbų mokèjimas, didinamas protinio darbo krūvis. Mažiau dèmesio skiriama mokinių sveikos gyvensenos ugdymui, fizinio aktyvumo skatinimui. Nors ivvairiais amžiaus tarpsniais keliami skirtingi fizinio ugdymo tikslai, tačiau ịvairūs autoriai, tirdami fizinio aktyvumo raišką mokykliniame amžiuje (Zaborskis ir kt., 1996; Strauss et al., 2001; Batutis, Kardelis, 2002; Nieman, 2002; Puišienè ir kt., 2005), pripažista, kad vaikų fizinis aktyvumas mažejja (Pate et al., 2005; Salmon et al., 2007). Kai kurie 
tyrèjai (Pate et al., 2005) yra tos nuomonès, kad sportavimas gali būti veiksminga priemoné, galinti atitraukti jaunimą nuo žalingu ipročių (narkotikų, svaigiuju gèrimų vartojimo). Atlikti tyrimai (Nieman, 2002) rodo, kad mažesnis nusikalstamumas yra sportuojančių moksleivių grupèse nei nesportuojančių. Minètasis autorius pateikia keletą teorijų, kurios tai patvirtina. Pavyzdžiui, stimulo-siekimo teorija — pasitenkinimas ir jaudulys, patirtas fizinès veiklos metu, didina šios veiklos poreiki, o pagal monotoniškumo teorija — sportiné veikla užima tam tikrą laiko tarpą. Tad vaikas, visas jeggas skirdamas sportui, mažiau laiko ir energijos turi nusikalstamam elgesiui reikštis. Teigiami santykiai šeimoje ir suaugusiuju pavyzdys taip pat gali skatinti sportinę veiklą, kuri mažina nusikalstamumą tarp sportuojančių paauglių.

Mokslinejje literatūroje aprašomas tyrimas (Trinkūnienè, Mozūrienè, 2005), kurio metu buvo ieškoma 5-8 klasiu mokiniu su sveikata ir judejimo aktyvumu susijusio fizinio pajègumo bei mokymosi pažangumo sąsajų. Tačiau tiriant fizinis aktyvumas nebuvo siejamas su mokymosi motyvacija ir psichosocialine sveikata. Mokiniu mokymosi pažangumas keičiantis amžiui mažèja, o jų fizinis pajègumas, atvirkščiai - gereja. Tačiau teigiamo ryšio tarp mokymosi pažangumo ir fizinio pajègumo nebuvo nustatyta.

Tyrimų, tiesiogiai analizuojančių fizinio aktyvumo sąsajas su mokymosi motyvacija, nèra daug. Daugiau yra analizuojančiu fizinio aktyvumo ir psichosocialinès sveikatos kintamujų sąsajas. Pavyzdžiui, nurodoma (Strauss et al., 2001; Batutis, Kardelis, 2002), kad tokie psichosocialinès sveikatos rodikliai kaip savigarba ir saviverte yra susiję su fizine sveikata ir tinkamumu sportui. Savo ruožtu sportavimas mažina nerimą, neigiamas emocijas, polinki i depresiją, priešiškumą kitiems (Pollock et al., 1998; Scully et al., 1998; Batutis, Kardelis, 2002; Kardelis, Stakytè, 2003). Nustatytas stiprus ryšys tarp igytu gebejjimu ir fizinès veiklos bei savigarbos (Pollock et al., 1998), t. y. fizinès veiklos metu teigiami bei neigiami potyriai yra tiesiogiai susiję su savigarba ir ịsitraukimu i fizinę veikla. Visgi mažai yra tyrimu, kurie sietu fizini aktyvuma, psichosocialine sveikata ir mokymosi motyvaciją, ypač tarp jaunimo mokyklu moksleiviu, kurie susiduria su tokiomis socializacijos problemomis kaip bendravimas, savigarba, elgesys, vertybių sistema ir kt. Todèl ypač aktualu ivertinti fizinio aktyvumo sąsajas su šiu mokinių mokymosi motyvacija ir psichosocialine sveikata. Tokiu tyrimų aktualumas paskatino atlikti tyrima, kuriuo kèlėme probleminị klausimą: ar egzistuoja tarp jaunimo mokyklu moksleivių fizinio aktyvumo, savigarbos, socialinès integracijos ir mokymosi motyvacijos sąsajos, t. y. ar jaunimo mokyklose fiziškai aktyvūs mokiniai yra geresnès socialinès integracijos, savigarbos ir turi aukštesnę mokymosi motyvaciją?

Probleminio klausimo formuluotè rèmèsi prielaida, kad egzistuoja sąsajos tarp fizinio aktyvumo bei psichosocialinès sveikatos rodiklių ir mokymosi motyvacijos, t. y. fiziškai aktyvesni paaugliai yra geresnès psichosocialinès sveikatos ir turi aukštesnę mokymosi motyvaciją.

Probleminio klausimo ir iš jo kylančios hipotezès formulavimas leido apibrežzti tyrimo objektą - fizinio aktyvumo, mokymosi motyvacijos bei psichosocialinès sveikatos sąsajas.

Tyrimo tikslas - atskleisti jaunimo mokyklu moksleiviu fizinio aktyvumo, psichosocialinès sveikatos ir mokymosi motyvacijos sąsajas.

\section{TYRIMO METODIKA}

Metodai. Tiriant mokiniu mokymosi motyvaciją taikyti du metodai: anketinè apklausa raštu (Zambacevičienè, Janulytè, 1998) ir interviu (Pileckaitè-Markovienè, 2001). Anketą sudarè 12 teiginių, kurie tyrimo metu buvo vertinami kaip mokymosi paskatos $(1$ - noriu užaugęs mokèti gerai dirbti; 2 - patinka sužinoti ką nors naujo; 3 - noriu gebèti ivveikti iškilusius sunkumus; 4 - mokytis mano pareiga; 5 - noriu tinkamai bendrauti su tévais, mokytojais, draugais; 6 - malonu sulaukti pagyrimo; 7 - noriu būti pirmūnu; 8 - noriu toliau mokytis; 9 - noriu būti draugu mégstamas; 10 - stengiuosi išvengti draugų kritikos; 11 - stengiuosi išvengti tèveliu, globejju (auklètojų) bausmių; 12 - stengiuosi išvengti mokytoju pastabų). Mokinių buvo prašoma kiekvieną paskatą ivvertinti balais pagal svarbą: labai jam svarbią paskata -5 balais, svarbią -4 , vidutiniškai svarbią -3 , mažai svarbią -2 , visai nesvarbią - 1. Interviu vyko su jaunimo mokyklų klasių auklètojais. Jie mokinių mokymosi motyvacijos charakteristikas $(1$ - visada atlieka namu darbu užduotis; 2 - visada atlieka užduotis klasejje; 3 - stropus; 4 - darbštus; 5 - mokosi savarankiškai, niekieno neverčiamas; 6 - prisiima atsakomybę už mokymosi rezultatus; 7 - greitai atlieka mokymosi užduotis; 8 - gerai sutaria su draugais; 9 - gabumai; 10 - mokymosi pasiekimai) taip pat vertino 5 balų sistema (čia 1 - žemiausias, 5 - aukščiausias vertinimas). Pagal 
klasių auklètojų ịvertintus moksleivių mokymosi pasiekimus 5 balu sistema buvo sudarytos dvi pasiekimų grupès, t. y. pažangūs ir nepažangūs moksleiviai. Pažangiems buvo priskirti tie mokiniai, kurie surinko daugiau kaip tris balus, o i nepažangių grupę pateko tie, kuriu mokymosi pasiekimai buvo įvertinti trimis ir mažiau balų. Tirti moksleiviai taip pat buvo suskirstyti i grupes pagal mokymosi motyvacijos charakteristikų vertinimą. Gavę sumini ịvertinimą, siekiantị 30 ir mažiau balų, pateko į žemos mokymosi motyvacijos grupę, surinkę 31 ir daugiau balu - $-\mathfrak{i}$ aukštos.

Savigarba tirta pagal C. Curie (1987) pasiūlytą metodiką, bendrą savigarbos lygi vertinančią nuo 0 iki 20 balų. Moksleiviai, surinkę iki 10 balų, buvo priskirti žemos savigarbos grupei, surinkę 11 ir daugiau - aukštos. Paauglių socialinei integracijai / izoliacijai tirti taikytas A. Eder (1989) klausimynas, kuriame šis psichosocialinès sveikatos rodiklis buvo analizuojamas pagal tirtų mokinių požiūrị i mokyklą, bendravimą su mokytojais, bendraamžiais ir draugais, santykius šeimoje. Tiriamajam surinkus 0 balų, jo socialinès integracijos lygis buvo vertinamas kaip žemas, $1-2$ balai rodè vidutini, o 3 balai - aukštą šio kintamojo lygi.

Apklausos metu moksleiviams buvo pateikti klausimai apie jų fizini aktyvumą. Pagal atsakymus į šiuos klausimus buvo sudarytos dvi fizinio aktyvumo grupès. I pirmą grupe pateko tie mokiniai, kurie be kūno kultūros pamokų papildomai lankè sporto šakos pratybas, i̇ antrą - tik lankantys kūno kultūros pamokas.

Tiriamieji. Imties tūrị tiriant visą populiaciją sudare 123 Kauno miesto jaunimo mokyklų 1517 metų moksleiviai (97 vaikinai ir 26 merginos). Tiriamujų kontingento pasirinkimą lèmé ta aplinkybè, kad kiekvienais metais dalis moksleivių dèl jų elgesio nebaigia vidurinès mokyklos ir iškrenta iš bendrojo lavinimo mokyklų. Tada jie patenka i jaunimo mokyklas, kur gali mokytis ir igyti pagrindinị išsilavinimą. Kita priežastis, lėmusi tokị pasirinkimą, yra jaunimo mokyklų koncepcija, kuri nurodo, kad jaunimo mokykloje gali mokytis 12-16 metu mokiniai, turintys mokymosi sunkumų ir 16-18 metų moksleiviai, dèl socialinių ekonominių priežasčių negalintys lankyti bendrojo lavinimo mokyklos (Jaunimo mokyklu koncepcija, 2005).

Procedūros. Tiriamuju apklausa suderinta su kiekvienos mokyklos administracija, specialistais (psichologu, socialiniu pedagogu) ir klasiu auklètojais. Atliekant tyrimą moksleiviams buvo garantuojamas jų duomenų anonimiškumas, nes nebuvo prašoma nurodyti nei vardo, nei pavardès, tačiau jiems buvo palikta teisè atsisakyti dalyvauti apklausoje. Apklausa vyko pamokų metu, kartu dalyvaujant ir pačiam tyrèjui (kad iškilus neaiškumams tiriamieji laiku gautų konsultaciją). Visi tyrimo dalyviai buvo supažindinti su tyrimo tikslu bei gavo reikiamą informaciją, kaip atsakyti i pateiktus klausimus ir teiginius. Tiriamujų buvo paprašyta pildyti anketą savarankiškai. Interviu su klasių auklètojais vyko prisilaikant savanoriškumo principo.

Statistinė analizė. Tyrimo duomenims apdoroti taikyti šie statistinès analizès metodai: dažnuminis procentinių duomenų skirstinys vertintas chi kvadrato ir kontingencijos koeficiento (KK) kriterijais (kadangi šių kriterijų duomenys iš esmès sutapo, straipsnyje pateikiamos tik chi kvadrato reikšmès). Kiekybinèms tyrimo duomenų charakteristikoms apskaičiuoti taikytos standartinès paklaidos (SP), standartiniai nuokrypiai (SN) ir Studento (t) kriterijus. Tyrimo kintamuju galimybių santykiams įvertinti taikyti logistinès regresijos modeliai (binarinis ir daugiareikšmis).

\section{REZULTATAI}

Remiantis pateiktais klasès auklètojų interviu duomenimis apie moksleiviu mokymosi motyvacines charakteristikas, sudarytos dvi grupès. Tie moksleiviai, kurie surinko 31 balą ir daugiau, buvo priskirti aukštos mokymosi motyvacijos grupei, o surinkę iki 30 balų pateko į žemos mokymosi motyvacijos grupę. Tyrimo duomenimis, $50,4 \%$ moksleivių buvo apibūdinti kaip turintys aukštą mokymosi motyvaciją, 49,6\% priskirti žemos mokymosi motyvacijos grupei. Lyginamoji analize lyčių grupèse parodè, kad 53\% vaikinų būdinga žema, $47 \%$ - aukšta mokymosi motyvacija. Tarp merginu — atitinkamai 35 ir $65 \%$

Taikant binarini logistinès regresijos modeli nustatyta, kiek moksleivių pateko i pažangaus ir nepažangaus mokymosi grupes. $81,3 \%$ tikslumu modelis išskyrè 71 nepažangu ir 29 pažangius moksleivius. Nepažangiu moksleiviu grupèje šis modelis $85,5 \%$ tikslumu išskyrè 71 nepažangų ir 12 pažangių moksleivių, pažangių grupėje — atitinkamai 11 ir 29 moksleivius (tikslumas - 72,5\%).

Noredami išsiaiškinti galimybių santykị tarp mokymosi pasiekimų ir moksleiviu motyvaciniu charakteristikų, taikème daugiareikšmi logistini regresijos modeli (žr. 1 lent.).

Iš 1 lentelèje pateiktų mokymosi motyvacinių charakteristikų išryškèjo tokios tendencijos: di- 


\begin{tabular}{|l|c|c|c|}
\hline $\begin{array}{l}\text { Motyvacinės } \\
\text { mokymosi charakteristikos }\end{array}$ & $\begin{array}{c}\text { Rodikliai } \\
\text { santykis }\end{array}$ & $\mathbf{9 5 , 0 \%}$ PI & $\begin{array}{l}\text { Reikšmingumo lentelè. Moksleivių motyva- } \\
\text { lygmuo } \\
\text { cinių charakteristikų galimy- } \\
\text { bių ir mokymosi pasiekimų } \\
\text { santykis (PI) }\end{array}$ \\
\hline Gabumai & 2,466 & $0,850-7,156$ & 0,097 \\
\hline Gerai sutaria su draugais & 0,268 & $0,096-, 753$ & 0,012 \\
\hline Greitai atlieka mokymosi užduotis & 0,898 & $0,326-2,473$ & 0,835 \\
\hline Prisiima atsakomybę už savo mokymosi rezultatus & 3,017 & $0,803-11,334$ & 0,102 \\
\hline Mokosi savarankiškai, niekieno neverčiamas & 0,551 & $0,215-1,413$ & 0,215 \\
\hline Darbštus & 1,515 & $0,551-4,167$ & 0,421 \\
\hline Stropus & 2,951 & $0,903-9,648$ & 0,073 \\
\hline Visada atlieka užduotis klasejje & 1,781 & $0,653-4,858$ & 0,260 \\
\hline Visada atlieka namų darbų užduotis & 1,431 & $0,930-2,203$ & 0,103 \\
\hline Lytis & 3,549 & $0,864-14,580$ & 0,79 \\
\hline
\end{tabular}

\begin{tabular}{|c|c|c|c|c|c|}
\hline Eil. Nr. & $\begin{array}{ll}\text { Mokymosi paskatos } & \text { Rodikliai } \\
\end{array}$ & Balai & $95,0 \%$ PI & $\begin{array}{c}\text { Reikšmingumo } \\
\text { lygmuo }\end{array}$ & \multirow[t]{6}{*}{$\begin{array}{l}2 \text { lentelè. Mokymosi paskatos, } \\
\text { labiausiai motyvuojančios } \\
\text { moksleivius mokytis }\end{array}$} \\
\hline 1. & Noriu toliau mokytis & 4,752 & $0,879-5,95$ & $\mathrm{p}<0,05$ & \\
\hline 2. & Mokytis mano pareiga & 3,856 & $0,653-5,133$ & $\mathrm{p}<0,05$ & \\
\hline 3. & Lytis & 2,959 & $0,684-4,216$ & $\mathrm{p}<0,05$ & \\
\hline 4. & Stengiuosi išvengti draugų kritikos & 1,161 & $0,523-2,642$ & $\mathrm{p}<0,05$ & \\
\hline 5. & Noriu užaugęs mokèti gerai dirbti & 0,954 & $0,089-2,174$ & $\mathrm{p}<0,03$ & \\
\hline
\end{tabular}

džiausias galimybes būti pažangiais turi merginos ir tie moksleiviai, kurie prisiima atsakomybę už savo mokymosi rezultatus, yra stropūs, gabūs. Mažiausias galimybes būti pažangiais modelis suteikia tiems moksleiviams, kurie gerai sutaria su draugais.

Nustatytas moksleivių motyvacinių charakteristiku galimybiu santykis su mokymosi pasiekimais leido įvertinti moksleivių procentinį skirstini pažangumo grupèse. Analizuojant lyčiu skirstini šiose grupese nustatyta, kad merginos nepažangiu moksleiviu grupeje sudare $35 \%$, pažangiu $-65 \%$ $(\mathrm{p}<0,05)$. Tuo tarpu $86 \%$ vaikinu pateko i nepažangiu grupę ir tik $14 \%$ - i pažangių $(\mathrm{p}<0,05)$. Lyginant vaikinų ir merginų mokymosi pasiekimus nesunku pastebèti, kad daugiau merginų nei vaikinu (atitinkamai 65 ir 14\%) pateko i̇ pažangiu moksleiviu grupe $(\mathrm{p}<0,05)$.

Kita moksleivių mokymosi motyvacinè charakteristika, turinti galimybių santyki su mokymosi pasiekimais, yra atsakomybe, kurią jie prisiima už savo mokymosi rezultatus. Nepažangiu moksleiviu grupejje neatsakingų moksleivių buvo $36 \%$, vidutiniškai atsakingu - $48 \%$ ir atsakingų - 16\%, pažangiu grupejje - atitinkamai 5, 18 ir $77 \%$. Tai rodo, kad pažangūs moksleiviai yra atsakingesni už savo mokymosi rezultatus nei nepažangūs.

Tiriant stropumo sąsajas su mokymosi pasiekimais pastebèta, kad i nepažangiu moksleiviu grupę pateko $30 \%$ nestropių moksleivių, 37\% vidutiniškai stropių ir $16 \%$ stropių, o i pažangių grupę pateko atitinkamai 1, 5 ir 34\% moksleivių $(\mathrm{p}<0,05)$. Lyginant gabumų raišką pažangumo grupèse pastebèta, kad i nepažangių moksleiviu grupę pateko $26 \%$ negabių, $38 \%$ vidutiniškai gabių ir 36\% gabių moksleivių, i pažangiu grupę - atitinkamai 3, 32 ir $65 \%(\mathrm{p}<0,05)$. Taigi galima teigti, kad pažangūs moksleiviai yra stropesni ir gabesni.

Taikant binarinị logistinès regresijos modelị, buvo analizuotas mokymosi motyvacinių charakteristikų ir mokymosi paskatų santykis (žr. 2 lent.).

Antros lentelès duomenys rodo, kad jaunimo mokyklu moksleivius labiausiai motyvuoja mokytis noras toliau mokytis. Moksleivių lytis taip pat išskirta kaip vienas iš veiksnių, lemiančiu mokymosi motyvacijos paskatu skirtumą vaikinų ir merginu grupèse. Ne mažiau svarbios ir tos mokymosi paskatos, kurios yra susijusios su draugu kritika ir noru užaugus mokèti gerai dirbti.

Išanalizavus psichosocialinès sveikatos rodiklius (savigarbą, socialinę integraciją), gauti šie jaunimo mokyklų moksleivių savigarbos rezultatai: vaikinu savigarbos vidutinis balas sieke $14,8 \pm 1,5$, o merginu $-14,0 \pm 2,8(p>0,05)$. Tai rodo, kad tirti moksleiviai yra aukštos savigarbos (i aukštos savigarbos grupę pateko 89,4\% tiriamujų). Tiriant socialinę integraciją / izoliaciją, nerasta statistiškai reikšmingo skirtumo lyties grupèse. Tiek merginoms (58\%), tiek vaikinams (55\%) būdingas vidutinis šio rodiklio balas. 


\begin{tabular}{|c|c|c|c|c|c|}
\hline \multirow[t]{6}{*}{$\begin{array}{l}3 \text { lentelè. Moksleivių moky- } \\
\text { mosi paskatos, susijusios su } \\
\text { savigarba }\end{array}$} & $\begin{array}{l}\text { Eil. } \\
\text { Nr. }\end{array}$ & $\begin{array}{l}\text { Rodikliai } \\
\text { Mokymosi paskatos }\end{array}$ & Balai & 95,0\% PI & $\begin{array}{c}\text { Reikšmingumo } \\
\text { lygmuo }\end{array}$ \\
\hline & 1. & Patinka sužinoti ką nors naujo & 2,99 & $0,625-10,61$ & $\mathrm{p}<0,05$ \\
\hline & 2. & Noriu užaugęs mokèti gerai dirbti & 1,63 & $0,746-2,589$ & $\mathrm{p}<0,02$ \\
\hline & 3. & $\begin{array}{l}\text { Noriu tinkamai bendrauti su tèvais, mokytojais, } \\
\text { draugais }\end{array}$ & 1,40 & $0,562-1,889$ & $\mathrm{p}<0,05$ \\
\hline & 4. & Malonu sulaukti pagyrimo & 1,10 & $0,77-3,733$ & $\mathrm{p}<0,02$ \\
\hline & 5. & Stengiuosi išvengti mokytojų pastabų & 0,95 & $0,649-2,18$ & $\mathrm{p}<0,05$ \\
\hline
\end{tabular}

4 lentelè. Tyrimo objekto kintamųjų sąsaja (abs. sk.)

\begin{tabular}{|l|c|c|c|c|c|c|}
\hline \multirow{2}{*}{$\begin{array}{l}\text { Fizinio } \\
\text { Rodtyvumo grupès }\end{array}$} & Aukšta & Žema & Aukšta & Žema & Aukšta & Žema \\
\cline { 2 - 7 } & 79 & 11 & 73 & 17 & 44 & 46 \\
\hline Fiziškai aktyvūs & 31 & 2 & 25 & 8 & 18 & 15 \\
\hline Nepakankamai aktyvūs & & & & \multicolumn{2}{c|}{ Socialinė integracija } & \multicolumn{2}{c|}{ Mokymosi motyvacija } \\
\hline
\end{tabular}

Rastas tarpusavio ryšys tarp psichosocialinès sveikatos kintamujų: $41 \%$ aukštos ir $23 \%$ žemos savigarbos moksleivių pateko į aukštos socialinès integracijos grupę. Žemos socialinès integracijos grupeje $4 \%$ tiriamujuc nustatyta aukšta, 23\% žema savigarba $\left(\chi^{2}=9,255 ; \mathrm{p}<0,05\right)$.

Sugretinus moksleivių savigarbą ir mokymosi motyvaciją apibūdinančius rodiklius pastebèta, kad 53,6\% aukštos savigarbos moksleivių apibūdinti kaip turintys aukštą mokymosi motyvacijos lygi, likusieji aukštos savigarbos moksleiviai $(46,4 \%)$ pateko i žemos mokymosi motyvacijos grupę $\left(\chi^{2}=4,343 ; \mathrm{p}<0,05\right)$. Tuo tarpu ryškesniu mokymosi motyvacijos skirtumų socialinès integracijos / izoliacijos grupèse nenustatyta.

Pritaikius binarini logistinès regresijos modeli dometasi, kokios moksleivių mokymosi paskatos, skatinančios juos mokytis, yra labiausiai susijusios su savigarba (žr. 3 lent.).

Iš 3 lentelejje pateiktų duomenu matyti, kad labiausiai su savigarba susijusi tokia mokymosi paskata kaip noras sužinoti ką nors naujo. Mažiau ryški noro išvengti mokytojų pastabų ir savigarbos sąsaja.

Tyrimo duomenimis, 73,2\% moksleiviu buvo fiziškai aktyvūs, likusieji $(26,8 \%)$ lankè tik kūno kultūros pamokas. Palyginus šių moksleivių psichosocialinès sveikatos rodiklius pastebèta, kad $73 \%$ aktyviai sportuojančių ir 27\% nepakankamai fiziškai aktyvių paauglių pateko į aukštos socialinès integracijos grupę $\left(\chi^{2}=5,64 ; p<0,05\right), 72 \%$ aktyviai sportuojančių ir $28 \%$ nepakankamai fiziškai aktyvių paauglių išsiskyrè aukšta savigarba $\left(\chi^{2}=1,58 ; \mathrm{p}<0,05\right)$.

Lyginant fizini aktyvumą su mokymosi pasiekimais rasta, kad nepažangių moksleivių grupejje fiziškai aktyvių berniukų buvo $81,7 \%$, merginu -
$25 \%$. Pažangių moksleiviu grupèje - atitinkamai 84,6 ir 50\%. Tai rodo, kad vienodas procentas fiziškai aktyvių berniukų pateko ir į aukštesnio, ir i žemesnio pažangumo grupes. Tuo tarpu nepažangių merginų grupeje daugiau buvo fiziškai pasyvių (75 ir $25 \% ; \mathrm{p}<0,05)$.

Ketvirtoje lenteleje pateikta tyrimo objekto kintamuju sąsaja. Duomenys rodo, kad daugiau fiziškai aktyvių moksleiviu patenka $\mathfrak{i}$ aukštos savigarbos $\left(\chi^{2}=9,7 ; p<0,05\right)$ ir socialinès integracijos $\left(\chi^{2}=2,1 ; p<0,05\right)$ grupes. Mokymosi motyvacijos atveju fiziškai aktyvių ir nepakankamai aktyvių moksleivių skaičius motyvacijos grupèse yra panašus.

\section{REZULTATŲ APTARIMAS}

Tyrimu siekta nustatyti $15-17$ metu jaunimo mokyklų moksleivių fizinio aktyvumo ir mokymosi motyvacijos bei psichosocialiniu sveikatos rodiklių sąsajas. Gauti rezultatai rodo, kad 53\% vaikinų ir 35\% merginų pateko į žemos mokymosi motyvacijos grupę. Tai gali būti susiję ne tik su mokymosi sunkumais, menkesniais gebejjimais ar specialiaisiais paauglio poreikiais, bet ir su jo psichosocialine sveikata. Žinant, kad sékmingą mokymosi motyvaciją lemia emocinis komfortas — pasitikejjimas savimi, tikejjimas savo sèkme, atlikimo ir išmokimo džiaugsmas - galima manyti, kad tie mokiniai, kurių mokymosi pasiekimai yra prasti, dažniau turi elgesio problemų ir asmeninių sunkumų, sukeliančių psichosocialinio neprisitaikymo riziką (Elias et al., 2003).

Lyties grupių skirstinio pažangumo grupėse analizè parodè, kad daugiau merginų nei vaikinų pateko į pažangių moksleiviu grupę. Taip pat paaiškejjo, kad jaunimo mokyklų moksleivių mokymosi 
pasiekimai priklauso ne tik nuo ju lyties, bet ir nuo tokių mokymąsi motyvuojančių charakteristikų kaip atsakomybè, kurią moksleivis prisiima už savo mokymosi rezultatus, gabumu, stropumo. Anot L. Rupšienès (2000), moksleivių pažangumą taip pat lemia sveikata, psichologiniai ypatumai, socialinè aplinka. Kita vertus, nors moksleivio mokymąsi lemia ivairūs motyvai, tačiau jų poveikis gali skirtis: vieni motyvai labiau skatina mokytis, kiti — mažiau, be to, jų poveikis priklauso ir nuo moksleivio amžiaus. Atlikto tyrimo duomenimis, labiausiai jaunimo mokyklu moksleivius motyvuoja mokytis noras tęsti mokslą. Tokie moksleiviai mąsto apie savo ateiti, sieja ją su būsima profesija. Tolimi ateities motyvai ateina ị vaikų sąmonę, kurie nuo pat mažens jaučiasi lygiateisiški, vertinami, dalyvauja suaugusiuju gyvenime. Tuo tarpu mokymosi nesėkmes lemia riboti ateities motyvai, kai moksleivis neturi tvirtu nuostatu dèl būsimos karjeros, nelabai supranta, kokią profesiją pasirinkti ir kaip ją igyti. Kita moksleiviams būdinga mokymosi paskata susijusi su pastangomis išvengti draugų kritikos. Tai galètu skatinti mokytojus teikti moksleiviui tokias užduotis, kurias atlikęs jis pajustų sėkmę.

Analizuojant mokymosi paskatas paaiškejjo, kad labiausiai su moksleiviu savigarba susijusios tokios mokymosi paskatos kaip noras sužinoti ką nors naujo, geriau pasirengti profesinei veiklai, sutarti su tèvais, mokytojais, draugais ir bendraamžiais, sulaukti pagyrimo, išvengti mokytoju pastabu. Tad jei paauglys bus nuolat kritikuojamas, tai galès turèti neigiamos itakos jo psichosocialinei sveikatai. J. Makari ir A. Zaborskio (2000) nuomone, tokie moksleiviu teiginiai kaip ,gera mokytis mokykloje“ arba ,patinka mokytis mokykloje“ yra laikomi psichologinès savijautos mokykloje požymiais. Neigiamas požiūris į mokyklą ir nenoras mokytis atsiranda trim atvejais: jei vaikas ikimokykliniame amžiuje nebuvo ipratintas riboti savo norų ir nugalèti sunkumus; jei prieš mokyklą buvo suformuota baimé; jei vaikui mokyklos gyvenimas iš anksto buvo nuspalvintas rožine spalva. Tokiu atveju nesusiformuoja jų vidinė pozicija, mokymosi motyvacija (Pileckaitè-Markoviené, 2001).

Lyginamoji tyrimo objekto kintamuju analizė parodẻ statistiškai patikimą ryši tarp psichosocialinès sveikatos rodikliu ir mokymosi motyvacijos, t. y. moksleiviai, patekę i aukštos savigarbos ir socialinès integracijos grupes, is kitų išsiskyrẻ aukšta mokymosi motyvacija. Tuo tarpu žemesnès socialinès integracijos paaugliai buvo žemos savigarbos. Kitu autoriu (Leipute, Kardelis, 2000; Batutis, Kardelis, 2002) tyrimai parodè, kad daugumai paauglių būdingas vidutinis socialinès integracijos lygmuo, tačiau paaugliai, gyvenantys globos namuose, labiau nei jų bendraamžiai, gyvenantys šeimose, yra žemos arba vidutinès socialinès integracijos. Be to, nustatyta, kad tie mokiniai, kurių mokymosi pasiekimai yra prasti, dažniau turi elgesio problemų ir asmeniniu sunkumų, galinčiu sukelti psichosocialinio neprisitaikymo riziką (Elias et al., 2003).

Fizinio aktyvumo ir psichosocialinès sveikatos rodiklių sąveikos analizè parodè, kad statistiškai reikšmingas skirtumas pastebimas tarp paauglių, kurie siekia puikiu sportinių rezultatų, ir tarp paauglių, su kūno kultūra ir sportu susiduriančiu tik per kūno kultūros pamokas (pastarieji išsiskyrè žemesne savigarba ir socialine integracija). Dauguma motyvų, skatinančių sportuoti, susiję su savigarbos poreikiu arba, kitaip tariant, su nepasitenkinimu savimi, savo išore ir galimybèmis. Tyrimai rodo, kad fiziniai pratimai galètu daryti itaką savigarbai. Žmogaus savigarba priklauso nuo triju veiksnių: visuomenèje užimamos padèties, gebejjimų ir fizinès būklès. Teigiamas savęs vertinimas padeda žmogui tobulèti, todèl treneris, stiprindamas sportininko viltis ir jų išsipildymą bei „Aš“ pojūti, padeda jam pagarbiau elgtis su savimi, atsikratyti gèdos, baimès ar pykčio. Tiriant savigarbos ir partnerystès poveikị emocinei būsenai nustatyta, kad ir mergaites, ir berniukai, gerai sutariantys su kartu sportuojančiais bendraamžiais, patiria kur kas didesnį džiaugsmą sportuodami, dažniau renkasi sportinę veiklą už mokyklos ribų. Be to, mergaičiu ir berniukų artimos draugystès suvokimas ir jos išgyvenimas yra susijęs su fiziniu savęs vertinimu, vidine motyvacija sportui bei jo rezultatams (Puišienė ir kt., 2005). Tyrimais (Nieman, 2002) nustatyta, kad sportas glaudžiai susijęs su asmens socializacijos procesais ir gali padèti vaikams atsispirti žalingai bendraamžiu itakai bei stabdyti ịsitraukimą į nusikalstamą veiklą (mažesnis nusikalstamumas pastebimas tarp sportuojančiu paaugliu). Taip atsitinka dèl to, kad sportuojant mokomasi laikytis nustatytų taisyklių, ir tai gali būti perkeliama ị kitas veiklos sritis. Taigi galima manyti, kad paskatinus jaunimo mokyklu moksleiviu fizini aktyvuma, itraukus juos i sportinę veiklą pagerètų ne tik ju psichosocialinès sveikatos rodikliai, bet ir atsirastu prielaidos, galinčios sustiprinti jų mokymosi motyvaciją.

Aptarti teiginiai apie atskleistas sąsajas leidžia numatyti tolesnių tyrimų perspektyvą norint ivertinti fizinio aktyvumo, psichosocialinès sveikatos rodikliu ir mokymosi motyvacijos tarpusavio 
ryšius bendrojo lavinimo vidurinėse mokyklose bei gautus tyrimo duomenis palyginti su jaunimo mokyklų moksleivių duomenimis. Pažymėtina, kad tyrimas atliktas jaunimo mokyklose, kuriose moksleivių skaičius svyruoja nuo 50 iki 130 (Jaunimo mokyklu koncepcija, 2005). Nors tyrimo metu pasirinkta 123 moksleiviu imtis buvo artima visai ju populiacijai, tačiau gautas skirtumas nevienodo dydžio lyties grupèse neleido tiksliau atskleisti sąsajų tarp tyrimo objekto kintamuju.

\section{IŠVADOS}

Jaunimo mokyklų moksleivių mokymosi motyvacijos, psichosocialinès sveikatos kintamuju ir fizinio aktyvumo sąsaju tyrimo rezultatai leido padaryti šias išvadas:

1. Jaunimo mokyklų moksleivius motyvuoja mokytis tokios mokymosi paskatos kaip noras toliau tęsti mokslus, pareigos jausmas, pastangos išvengti draugų kritikos ir noras užaugus mokèti gerai dirbti.

2. Nerasta statistiškai reikšmingo skirtumo tarp psichosocialinès sveikatos rodiklių (savigarbos ir socialinès integracijos) lyties grupèse.

3. Nustatytas savigarbos ir socialinès integracijos tarpusavio ryšys, t. y. aukštos socialinès integracijos moksleiviai iš kitu išsiskyre ir aukšta savigarba.

4. Fiziškai aktyvesni moksleiviai buvo aukštos savigarbos ir geresnès socialinès integracijos.

5. Lyginamoji fizinio aktyvumo ir mokymosi pasiekimu analizė parodè, kad abiejose grupèse buvo vienodas procentas fiziškai aktyvių vaikinų, o nepažangių merginų grupèje buvo daugiau fiziškai pasyvių. Mokymosi motyvacijos grupėse fiziškai aktyvių ir nepakankamai aktyvių moksleivių skaičius buvo panašus.

6. Lyginamoji tyrimo objekto kintamujuc analizè atskleide jų tarpusavio sąsajas: aukštesnès savigarbos buvo tie moksleiviai, kuriuos skatina mokytis tokios paskatos kaip noras sužinoti ką nors naujo, užaugus mokèti gerai dirbti ir tinkamai bendrauti su tèvais, mokytojais, draugais, taip pat jie buvo fiziškai aktyvesni ir geriau socialiai integruoti.

\section{LITERATŪRA}

Batutis, O., Kardelis, K. (2002). Moksleiviu socialinès izoliacijos, integracijos ir savigarbos sąsaja su fiziniu aktyvumu. Ugdymas. Küno kultūra. Sportas, 2 (43), 10-16.

Curie, C. (1987). Gender differences in self-esteem and health related behavior in Scottish schoolchildren. Paper presented at WHO: HBSC meeting. Budapest.

Eder, A. (1989). Health Behavior in School-Aged Children (HBSC). A WHO Cross-National Survey: Research Protocol for the 1989-1990 Study. Norway: University of Bergen Research Centre for Health Promotion.

Elias, L. C., Marturano, E. M., Giurlani, A. G. (2003). Treating boys with low school achievement and behavior problems: Comparison of two kinds of intervention. Psychological Representative, 92 (1), 105-116.

Jaunimo mokyklu koncepcija. (2005). Patvirtinta Lietuvos Respublikos švietimo ir mokslo ministro $2005 \mathrm{~m}$. gruodžio 12 d. isakymu Nr. ISAK-2549.

Kardelis, K., Stakyte, S. (2003). Skirtingo fizinio aktyvumo paaugliu mokymosi motyvacijos ir psichosocialinès sveikatos duomenu sąsaja. Sporto mokslas, 4 (34), 39- 43.

Leiputè, O., Kardelis, K. (2002). Vaikų globos namų ugdytiniu psichosocialinès sveikatos ir mokymosi motyvacijos duomenų sąsaja. Ugdymas. Küno kultūra. Sportas, 1 (42), $15-21$.

Makari, J., Zaborskis, A. (2000). Moksleivių savijauta ir jos sąsaja su psichologine mokyklos aplinka. Medicina, 36 (4), 332-341.

Nieman, P. (2002). Psychosocial aspects of physical activity. Paediatrics and Child Health, 7 (5), 309-312.

Pate, R. R., Heath, G. W., Dowda, M., Trost, S. G. (2005). Associations between physical activity and other health behaviors in a representative sample of US adolescents. Department of Exercise Science, School of Public Health, University of South Carolina, Columbia 29208, USA.

Pileckaitè-Markovienè, M. (2001). Pradinių klasių moksleivių mokymosi motyvacija, psichologinè savijauta ir mokyklinis nerimastingumas. Psichologija, 37-49.

Pollock, M. L., Gaesser, G. A., Butcher, J. D. et al. (1998). The recommended quantity and quality of exercise for developing and maintaining cardiorespiratory and muscular fitness, and flexibility in healthy adults. Medicine and Science in Sports and Exercise, 30, 975-991.

Puišienè, E., Volbekienė, V., Kavaliauskas, S., Čikotienė, I. (2005). Physical education in Lithuania. In U. Pühse, M. Gerber (Eds.), International Comparison of Physical Education: Concepts, Problems, Prospects. Oxford: Meyer \& Meyer Sport. P. 441- 459.

Rupšienė, L. (2000). Nenoras mokytis kaip socialinis pedagoginis reiškinys (monografija). Klaipeda: KU leidykla.

Salmon, J., Booth, M. L., Phongsavan, P. et al. (2007). Promoting physical activity participation among children and adolescents. Epidemiologic Reviews, 29 (1), $144-159$.

Scully, D., Kremer, J., Meade, M. M. et al. (1998). Physical exercise and psychological well being: A critical review. British Journal of Sports Medicine, 32, 111-120.

Strauss, R. S., Rodzilsky, D., Burack, G. et al. (2001). Psychosocial Correlates of Physical Activity in Healthy Children, Archives of Pediatrics \& Adolescent Medicine, 155, 897-902.

Trinkūnienè, L., Mozūrienè, I. (2005). Pagrindinès mokyklos mokiniu (5-8 klasiu) su sveikata ir judèjimo galimy- 
bèmis susijusio fizinio pajègumo ir mokymosi pažangumo rezultatu sqsaja: Lietuvos mokslinè konferencija ,, Sporto mokslas-2005“, 82.

Zaborskis, A., Žemaitienè, N., Šumskas, L., Diržytė, A. (1996). Moksleiviu gyvenimo būdas ir sveikata. Vilnius: Leidybos centras.
Zambacevičienė, E. P., Janulytė, D. (1998). Pradiniu klasiu mokiniu mokymosi motyvai: skirtumai, dinamika, formavimas: mokslines praktinès konferencijos „Pradinè mokykla demokratinejjančioje visuomeneje" medžiaga (pp. 182-186). Šiauliai.

\title{
LINKS OF PHYSICAL ACTIVITY OF YOUTH SCHOOL PUPILS WITH THEIR LEARNING MOTIVATION, SELF-RESPECT AND SOCIAL INTEGRATION
}

\author{
Edita Vainiené $\dot{ }^{1}$, Kęstutis Kardelis ${ }^{2}$ \\ Kaunas P. Eimutis youth school ${ }^{1}$, Lithuanian Academy of Physical Education ${ }^{2}$,
} Kaunas, Lithuania

\begin{abstract}
In their daily life Youth schools teachers deal with adolescents, who get into such schools because of various reasons for example: insufficient parents' care, hard social-economic conditions, alternations in selfesteem, reduced aspirations and failures in educational process, too much anxiety, seeking for independence, dispositions to practice and sport's activities, structure of intellect, emotional and behavioral disorders. That is why the teachers from youth schools often have difficulties when they want to stimulate pupils' learning motivation, which can also be related to physical activity. In our opinion physical activity could be one of the factors capable of making positive influence on pupils' attitudes towards their school.

Thus, the aim of our research, was to reveal the links among youth school pupils' physical activity, learning motivation and psychosocial health. The research methods used to estimate the learning motivation were the questionnaire inquiry (Zambacevičienè, Janulytė, 1998) and the interview (Pileckaitè-Markovienė, 2001). Pupils' social integration/isolation was estimated applying A. Eder's (1989) questionnaire which also included questions about their physical activity. Pupils' self-esteem was analysed using the methodology proposed by C. Curie (1987).

The sample in the research, investigating the whole population, consisted of $15-17$ year old pupils (97 boys and 26 girls) from all youth schools in Kaunas $(\mathrm{n}=123)$.

The results showed that pupils from the youth schools were motivated by such incentives as a wish to continue learning, a sense of duty, efforts to avoid friends' criticism and wish to work well when they are adults.

We observed an interrelation between psychosocial health indices (social integration and self-esteem) among those pupils who demonstrated high social integration and high self-esteem. The study showed that there were no statistically significant gender differences in social integration and self-esteem, but indices of learning motivation and achievements were higher for girls than for boys.

According to physical activity we found that boys were more physically active than girls. Research results showed that more physically active pupils demonstrated higher self-esteem, and they were more integrated socially. Comparative analysis of pupils' learning motivation, psychosocial health indices and physical activity revealed their interrelation: more physically active pupils expressed higher level of selfesteem and were better socially integrated. Higher self-esteem indices were typical of those pupils who were motivated by incentives such as wish to know something new, desire to learn to work well when they are adults and to communicate with parents, teachers and friends with respect.
\end{abstract}

Keywords: physical activity, learning motivation, psychosocial health indices.

Gauta 2007 m. lapkričio 13 d.

Received on November 13, 2007

Priimta $2008 \mathrm{~m}$. vasario $20 \mathrm{~d}$.

Accepted on February 20, 2008
Edita Vainienè

P. Eimučio jaunimo mokykla

(Kaunas P. Eimutis Youth School)

V. Krèvès pr. 50, LT-50406 Kaunas

Lietuva (Lithuania)

Tel +370 37314694

E-mail editae_1999@yahoo.com 